\title{
Influence of organic fertilizers on the water and food regime of meadow-chernozem soil
}

\author{
Igor Bobrenko ${ }^{1}$, Natalia Goman ${ }^{1 *}$ Victor Kormin ${ }^{1}$, Nadezhda Trubina ${ }^{1}$, and Marina \\ Sklyarova ${ }^{1}$ \\ ${ }^{1}$ Omsk State Agrarian University named after P.A. Stolypin, Institutskaya pl., 1, Omsk, 644008, \\ Russian Federation
}

\begin{abstract}
The research is based on the results of studying the effect of solid organic fertilizers based on cattle manure (cattle) of various storage periods on the supply of productive moisture and the chemical composition of meadow-chernozem soil. The studies were carried out at LLC RUSKOM-Agro, Omsk region in 2017-2018. The application of organic fertilizers significantly increases the content of nitrate nitrogen (from very low to very high levels), mobile phosphorus and potassium. In the first year of aftereffect, manure doses continue to have a significant impact on the nutrient regime of the soil. Moisture reserves before sowing were characterized as good (133-154 mm) without significant changes when applying manure.
\end{abstract}

\section{Introduction}

The soil cover of Siberia is very diverse, and the water and food regime of soils used in agriculture depends on various causes of natural and anthropogenic origin [1-5].

Moisture security is the leading factor in soil fertility and determines the receipt of high and stable yields of grain crops. Soil moisture becomes especially important in the foreststeppe and steppe conditions, where the productive moisture of the soil layer is a limiting factor with high heat supply. With an insignificant and unstable atmospheric moisture during the formation of the biological crop yield, the role of a regulator that mitigates atmospheric drought is played by spring reserves of productive moisture in the soil. Optimization of the water regime in dry farming is a very difficult problem. Therefore, the search for ways of a more complete and rational use of precipitation in the conditions of intensification of agriculture is of particular relevance.

Moisture reserves in the soil, their distribution is determined by many factors: the amount of atmospheric precipitation, agrohydrological and physical properties of the soil, the content of organic matter and basic nutrients, biological characteristics of plants, agrotechnical measures, including the use of mineral and organic fertilizers, various soil treatments, the placement of crops in crop rotation [6-9].

\footnotetext{
${ }^{*}$ Corresponding author: nv.goman@omgau.org
} 
The dietary regime of the soil affects the yield of agricultural crops [10-12]. Organic fertilizers contain a significant amount of nutrients and, when used in agriculture, a positive effect on soil fertility in various soil and climatic conditions is noted, which also affects the level of productivity of cultivated plants [13-16].

\section{Methods and equipment}

The research was carried out at the experimental plots of LLC RUSKOM-Agro in the Omsk region and at the Department of Agrochemistry and Soil Science of the Federal State Budgetary Educational Institution of Higher Education Omsk State Agrarian University in 2017-2018. The studied object was the spring wheat plants Pamyat Aziev; the soil was meadow chernozem, low-power, low-humus, heavy loamy. Content in the soil before sowing N-NO3 - 2.14-10.2, P2O5 - 146-195, K2O - 294-425 mg / kg.

The location of the plots on the experimental site is systematic. The experiment was repeated three times. Plot area $-20 \mathrm{~m}^{2}$; accounting area $-16 \mathrm{~m}^{2}$. Agrotechnics are common for the zone.

Laboratory studies were carried out at the Department of Agrochemistry and Soil Science of the Federal State Budgetary Educational Institution of Higher Education Omsk State Agrarian University. In soil samples, the content of nitrate nitrogen with disulfophenolic acid was determined according to Grandval-Lyazh; the amount of mobile phosphorus and potassium - from one extract according to Chirikov (GOST 26204-84).

\section{Results}

In the absence of reliable forecasts for the precipitation of the growing season, it is of practical importance to identify the role of soil moisture reserves before sowing on the formation of agricultural crops. Assessment of the relationship between pre-sowing soil moisture reserves and yield, based on long-term stationary experiments on chernozem soil in the southern forest-steppe of Western Siberia, showed that the reserves of productive moisture in the soil in the $0-100 \mathrm{~cm}$ layer determined the yield of crops [7]. In our studies, the moisture reserves before sowing spring wheat were and were characterized as good (133-154 mm) without significant changes in the variants of the experiment (Table 1).

Table 1. Reserves of productive moisture in the soil before sowing wheat in the $0-100 \mathrm{~cm}$ layer, depending on the duration of storage and doses of cattle manure, mm, 2017-2018.

\begin{tabular}{|l|c|c|c|c|c|}
\hline \multirow{2}{*}{ Option } & \multicolumn{5}{|c|}{ Storage duration (months) } \\
\cline { 2 - 6 } & $\mathbf{4}$ & $\mathbf{6}$ & $\mathbf{8}$ & $\mathbf{1 0}$ & $\mathbf{1 2}$ \\
\hline & \multicolumn{5}{|c|}{2017} \\
\hline \multirow{3}{*}{ Control } & 138 & 135 & 133 & 140 & 142 \\
\cline { 2 - 6 } & \multicolumn{5}{|c|}{2018} \\
\cline { 2 - 6 } & 151 & 148 & 154 & 146 & 152 \\
\hline
\end{tabular}

Indicators of productive moisture reserves in the tillering phase and after harvesting wheat in the soil layer $0-30 \mathrm{~cm}$ are presented in Table 2 and are also typical for the zone. 
Table 2. Productive moisture reserves in the soil in the tillering phase in the $0-30 \mathrm{~cm}$ layer, depending on the duration of storage and doses of cattle manure, mm, 2018.

\begin{tabular}{|c|c|c|c|c|c|}
\hline \multirow{2}{*}{ Option } & \multicolumn{5}{|c|}{ Storage duration (month) } \\
\cline { 2 - 6 } & $\mathbf{4}$ & $\mathbf{6}$ & $\mathbf{8}$ & $\mathbf{1 0}$ & $\mathbf{1 2}$ \\
\hline \multicolumn{5}{|c|}{ Act $(2017)$} \\
\hline Control & 16,3 & 15,6 & 15,6 & 14,8 & 16,2 \\
\hline $20 \mathrm{t} / \mathrm{ha}$ & 15,0 & 15,8 & 16,3 & 15,7 & 15,9 \\
\hline $30 \mathrm{t} / \mathrm{ha}$ & 14,6 & 17,1 & 15,1 & 18,1 & 15,2 \\
\hline $40 \mathrm{t} / \mathrm{ha}$ & 15,4 & 17,7 & 14,6 & 17,8 & 17,5 \\
\hline $50 \mathrm{t} / \mathrm{ha}$ & 14,7 & 16,9 & 14,8 & 17,8 & 15,9 \\
\hline $60 \mathrm{t} / \mathrm{ha}$ & 14,6 & 16,7 & 19,8 & 19,0 & 16,2 \\
\hline \multicolumn{7}{|c|}{ Aftereffect (2018) } \\
\hline Control & 15,2 & 15,3 & 18,5 & 14,7 & 19,1 \\
\hline $20 \mathrm{t} / \mathrm{ha}$ & 15,5 & 15,7 & 17,5 & 16,1 & 18,5 \\
\hline $30 \mathrm{t} / \mathrm{ha}$ & 16,1 & 15,2 & 18,0 & 14,7 & 16,0 \\
\hline $40 \mathrm{t} / \mathrm{ha}$ & 19,2 & 18,0 & 14,3 & 14,4 & 15,4 \\
\hline $50 \mathrm{t} / \mathrm{ha}$ & 17,5 & 16,0 & 16,7 & 19,3 & 16,8 \\
\hline $60 \mathrm{t} / \mathrm{ha}$ & 16,2 & 15,9 & 14,7 & 17,1 & 16,3 \\
\hline
\end{tabular}

Table 3. Productive moisture reserves in the soil after harvesting wheat in a layer of $0-30 \mathrm{~cm}$ depending on cattle manure, $\mathrm{mm}, 2018$.

\begin{tabular}{|c|c|c|c|c|c|}
\hline \multirow{2}{*}{$\begin{array}{c}\text { Option } \\
\text { storage duration (months) / dose, } \\
\text { t / ha } \\
\end{array}$} & \multirow{2}{*}{$\begin{array}{c}\text { Layer } \\
\text { soil, cm }\end{array}$} & \multicolumn{2}{|c|}{ Action } & \multicolumn{2}{|c|}{ Aftereffect } \\
\hline & & $\%$ & $\mathrm{~mm}$ & $\%$ & $\mathrm{~mm}$ \\
\hline \multirow{6}{*}{ Control } & $0-20$ & 28,4 & 36,5 & 33,3 & 47,3 \\
\hline & $20-40$ & 23,2 & 28,7 & 24,3 & 31,3 \\
\hline & $40-60$ & 23,2 & 34,8 & 17,7 & 20,5 \\
\hline & $60-80$ & 18,6 & 28,1 & 15,0 & 18,0 \\
\hline & $80-100$ & 16,9 & 23,7 & 14,5 & 16,5 \\
\hline & $0-100$ & & 151,8 & & 133,6 \\
\hline \multirow{6}{*}{$4 / 60$} & $0-20$ & 33,2 & 47,1 & 28,5 & 36,7 \\
\hline & $20-40$ & 29,2 & 43,1 & 26,3 & 36,1 \\
\hline & $40-60$ & 19,2 & 24,4 & 21,4 & 30,1 \\
\hline & $60-80$ & 16,3 & 21,6 & 18,9 & 28,9 \\
\hline & $80-100$ & 14,0 & 15,0 & 19,7 & 32,1 \\
\hline & $0-100$ & & 151,2 & & 163,9 \\
\hline \multirow{6}{*}{$6 / 60$} & $0-20$ & 33,3 & 47,3 & 27,6 & 34,7 \\
\hline & $20-40$ & 27,2 & 38,3 & 22,8 & 27,7 \\
\hline & $40-60$ & 16,4 & 17,1 & 16,9 & 18,4 \\
\hline & $60-80$ & 14,8 & 17,4 & 15,3 & 18,8 \\
\hline & $80-100$ & 15,8 & 20,4 & 16,1 & 21,3 \\
\hline & $0-100$ & & 140,5 & & 120,9 \\
\hline \multirow{6}{*}{$8 / 60$} & $0-20$ & 33,0 & 46,6 & 21,5 & 21,3 \\
\hline & $20-40$ & 26,7 & 37,1 & 20,6 & 22,4 \\
\hline & $40-60$ & 24,5 & 38,2 & 22,2 & 32,2 \\
\hline & $60-80$ & 18,3 & 27,2 & 17,6 & 25,3 \\
\hline & $80-100$ & 16,9 & 23,7 & 17,7 & 26,1 \\
\hline & $0-100$ & & 172,8 & & 127,3 \\
\hline \multirow{6}{*}{$10 / 60$} & $0-20$ & 34,2 & 49,2 & 25,0 & 29,0 \\
\hline & $20-40$ & 21,4 & 24,4 & 19,9 & 20,8 \\
\hline & $40-60$ & 15,8 & 15,6 & 16,0 & 16,1 \\
\hline & $60-80$ & 14,5 & 16,6 & 15,1 & 18,3 \\
\hline & $80-100$ & 15,7 & 20,1 & 16,1 & 21,3 \\
\hline & $0-100$ & & 125,9 & & 105,5 \\
\hline \multirow{6}{*}{$12 / 60$} & $0-20$ & 27,6 & 34,7 & 25,6 & 30,3 \\
\hline & $20-40$ & 19,5 & 19,8 & 20,2 & 21,5 \\
\hline & $40-60$ & 14,9 & 13,2 & 19,4 & 24,9 \\
\hline & $60-80$ & 11,5 & 8,2 & 15,9 & 20,5 \\
\hline & $80-100$ & 12,4 & 10,2 & 13,3 & 12,9 \\
\hline & $0-100$ & & 86,1 & & 97,2 \\
\hline
\end{tabular}


When applied, organic fertilizers affect the content of available nutrients in the soil $[8,13,17]$. The studies have studied the effect and aftereffect of 1 -year doses of manure on the fertility of meadow-chernozem soil. It should be noted that there is a significant increase in the level of nitrate nitrogen in the soil under the action of fertilizer. The provision of wheat plants with nitrate nitrogen in the germination phase increased by more than 1.5-2.0 times with the introduction of 40-60 $\mathrm{t} / \mathrm{ha}$ of manure with a storage duration of 8-12 months. The content of nitrate nitrogen in the soil was at the level of $20.5-29.1 \mathrm{mg} / \mathrm{kg}$ soil (in the control 9.1-11.8). By the time of harvesting, the content of this element according to the variants of the experiment began to differ less significantly due to its consumption by wheat plants (Table 4).

With the aftereffect of manure in the first year, the provision of wheat plants with nitrate nitrogen in the germination phase increased by more than 1.5 times with the introduction of 40-60 t / ha of manure with a storage duration of 8-12 months. The content of nitrate nitrogen in the soil is $12.6-18.0 \mathrm{mg} / \mathrm{kg}$ of soil (in the control 10.4-11.4). The reason for this increase is the decomposition of organic matter of manure, the processes of ammonification and nitrification. Correlation analysis established the dependence of the content of nitrate nitrogen in the soil on the doses of fertilizers in action in the germination phase:

$\begin{array}{lcc}4 \text { months of storage } & \mathrm{y}=0,156 \mathrm{x}+9,07 & \mathrm{r}=0,90 \\ 6 \text { months of storage } & \mathrm{y}=0,121 \mathrm{x}+11,02 & \mathrm{r}=0,67 \\ 8 \text { months of storage } & \mathrm{y}=0,149 \mathrm{x}+10,30 & \mathrm{r}=0,75 \\ 10 \text { months of storage } & \mathrm{y}=0,187 \mathrm{x}+9,61 & \mathrm{r}=0,81 \\ 12 \text { months of storage } & \mathrm{y}=0,086 \mathrm{x}+11,49 & \mathrm{r}=0,71\end{array}$

The supply of wheat plants with mobile forms of phosphorus under the action of manure is very high and the need for plants in this element is virtually absent (Table 5).

Table 4. Influence of storage duration and doses of cattle manure on the content of nitrate nitrogen in the soil in the $0-40 \mathrm{~cm}$ layer, $\mathrm{mg} / \mathrm{kg}$ of soil.

\begin{tabular}{|c|c|c|c|c|c|}
\hline \multirow{2}{*}{ Option } & \multicolumn{5}{|c|}{ Storage duration (months) } \\
\hline & 4 & 6 & 8 & 10 & 12 \\
\hline \multicolumn{6}{|c|}{ Seedlings act } \\
\hline Control & 9,1 & 11,5 & 10,5 & 10,0 & 11,8 \\
\hline $30 \mathrm{t} / \mathrm{ha}$ & 13,8 & 15,6 & 15,2 & 16,0 & 14,7 \\
\hline $40 \mathrm{t} / \mathrm{ha}$ & 14,4 & 14,0 & 18,4 & 20,5 & 21,4 \\
\hline \multicolumn{6}{|c|}{ aftereffect } \\
\hline Control & 10,4 & 11,4 & 10,1 & 10,1 & 10,2 \\
\hline $20 \mathrm{t} / \mathrm{ha}$ & 12,0 & 11,8 & 12,1 & 12,9 & 10,9 \\
\hline $30 \mathrm{t} / \mathrm{ha}$ & 12,5 & 13,5 & 12,2 & 14,5 & 11,5 \\
\hline $40 \mathrm{t} / \mathrm{ha}$ & 12,6 & 13,1 & 14,4 & 15,8 & 15,4 \\
\hline $20 \mathrm{t} / \mathrm{ha}$ & 5,3 & 7,3 & 7,9 & 7,5 & 5,9 \\
\hline $30 \mathrm{t} / \mathrm{ha}$ & 6,6 & 8,5 & 6,0 & 7,3 & 5,5 \\
\hline $40 \mathrm{t} / \mathrm{ha}$ & 8,5 & 8,4 & 8,5 & 6,5 & 6,8 \\
\hline $50 \mathrm{t} / \mathrm{ha}$ & 8,9 & 8,3 & 8,4 & 8,3 & 6,7 \\
\hline $60 \mathrm{t} / \mathrm{ha}$ & 9,6 & 8,2 & 7,7 & 7,7 & 7,9 \\
\hline \multicolumn{6}{|c|}{ aftereffect } \\
\hline Control & 3,2 & 2,1 & 2,3 & 1,4 & 1,8 \\
\hline $20 \mathrm{t} / \mathrm{ha}$ & 4,8 & 2,5 & 4,5 & 2,2 & 3,9 \\
\hline $30 \mathrm{t} / \mathrm{ha}$ & 6,0 & 5,8 & 3,9 & 5,4 & 3,9 \\
\hline $40 \mathrm{t} / \mathrm{ha}$ & 5,1 & 4,7 & 3,2 & 5,9 & 3,9 \\
\hline
\end{tabular}


Application of manure in doses of 40-60 $\mathrm{t} /$ ha after 10-12 months of storage increases the content of mobile phosphorus (according to Chirikov) in the soil by $19-71 \%$. With the aftereffect of manure in the first year, the effect on the phosphorus content is even greater than in the action and it increases from $190-208 \mathrm{mg} / \mathrm{kg}$ in the control to $235-314 \mathrm{mg} / \mathrm{kg}$ at doses of 50 and $60 \mathrm{t} / \mathrm{ha}$. The reason is that during that period there was a large mineralization of manure.

Table 5. Influence of storage duration and doses of cattle manure on the content of mobile phosphorus in the soil in the $0-20 \mathrm{~cm}$ layer, $\mathrm{mg} / \mathrm{kg}$ of soil.

\begin{tabular}{|c|c|c|c|c|c|}
\hline \multirow{2}{*}{ Option } & \multicolumn{5}{|c|}{ Storage duration (months) } \\
\hline & 4 & 6 & 8 & 10 & 12 \\
\hline \multicolumn{6}{|c|}{$\begin{array}{c}\text { seedlings } \\
\text { act }\end{array}$} \\
\hline Control & 189 & 193 & 204 & 208 & 205 \\
\hline $20 \mathrm{t} / \mathrm{ha}$ & 235 & 265 & 255 & 235 & 258 \\
\hline $30 \mathrm{t} / \mathrm{ha}$ & 245 & 288 & 255 & 248 & 274 \\
\hline $40 \mathrm{t} / \mathrm{ha}$ & 260 & 255 & 268 & 258 & 292 \\
\hline $50 \mathrm{t} / \mathrm{ha}$ & 250 & 245 & 272 & 262 & 312 \\
\hline $60 \mathrm{t} / \mathrm{ha}$ & 245 & 250 & 274 & 270 & 354 \\
\hline \multicolumn{6}{|c|}{ aftereffect } \\
\hline Control & 190 & 195 & 204 & 208 & 205 \\
\hline $20 \mathrm{t} / \mathrm{ha}$ & 215 & 225 & 215 & 235 & 228 \\
\hline $30 \mathrm{t} / \mathrm{ha}$ & 223 & 228 & 235 & 245 & 234 \\
\hline $40 \mathrm{t} / \mathrm{ha}$ & 250 & 235 & 248 & 256 & 244 \\
\hline $50 \mathrm{t} / \mathrm{ha}$ & 260 & 245 & 252 & 261 & 300 \\
\hline $60 \mathrm{t} / \mathrm{ha}$ & 275 & 250 & 274 & 271 & 314 \\
\hline \multicolumn{6}{|c|}{$\begin{array}{c}\text { seedlings } \\
\text { act }\end{array}$} \\
\hline Control & 145 & 153 & 197 & 137 & 198 \\
\hline $20 \mathrm{t} / \mathrm{ha}$ & 156 & 153 & 176 & 142 & 218 \\
\hline $30 \mathrm{t} / \mathrm{ha}$ & 190 & 182 & 212 & 186 & 296 \\
\hline $40 \mathrm{t} / \mathrm{ha}$ & 150 & 120 & 202 & 174 & 249 \\
\hline $50 \mathrm{t} / \mathrm{ha}$ & 219 & 191 & 147 & 237 & 253 \\
\hline $60 \mathrm{t} / \mathrm{ha}$ & 219 & 245 & 159 & 164 & 323 \\
\hline \multicolumn{6}{|c|}{ aftereffect } \\
\hline Control & 159 & 178 & 254 & 278 & 284 \\
\hline $20 \mathrm{t} / \mathrm{ha}$ & 197 & 174 & 144 & 174 & 202 \\
\hline $30 \mathrm{t} / \mathrm{ha}$ & 226 & 180 & 164 & 221 & 198 \\
\hline $40 \mathrm{t} / \mathrm{ha}$ & 150 & 154 & 202 & 263 & 256 \\
\hline $50 \mathrm{t} / \mathrm{ha}$ & 215 & 224 & 160 & 231 & 284 \\
\hline $60 \mathrm{t} / \mathrm{ha}$ & 226 & 269 & 162 & 342 & 288 \\
\hline
\end{tabular}

Observations of the potassium regime of the culture showed that the content of mobile potassium (according to Chirikov) in the soil is very high - 402-512 $\mathrm{mg} / \mathrm{kg}$ of soil (Table 6 ). When manure is applied, the potassium content in the soil increases by more than 10 $24 \%$. The aftereffect of manure in the first year increases the content of mobile potassium in the germination phase from 303-399 in control to $340-602 \mathrm{mg} / \mathrm{kg}$ in fertilized variants. 
Table 6. Influence of storage duration and doses of cattle manure on the content of mobile potassium in the soil in the $0-20 \mathrm{~cm}$ layer, $\mathrm{mg} / \mathrm{kg}$ of soil.

\begin{tabular}{|c|c|c|c|c|c|}
\hline \multirow{2}{*}{ Option } & \multicolumn{5}{|c|}{ Storage duration (months) } \\
\hline & 4 & 6 & 8 & 10 & 12 \\
\hline \multicolumn{6}{|c|}{$\begin{array}{c}\text { seedlings } \\
\text { act }\end{array}$} \\
\hline Control & 434 & 402 & 408 & 403 & 399 \\
\hline $20 \mathrm{t} / \mathrm{ha}$ & 440 & 416 & 421 & 435 & 425 \\
\hline $30 \mathrm{t} / \mathrm{ha}$ & 461 & 437 & 426 & 453 & 468 \\
\hline $40 \mathrm{t} / \mathrm{ha}$ & 464 & 454 & 430 & 406 & 453 \\
\hline $50 \mathrm{t} / \mathrm{ha}$ & 480 & 442 & 452 & 453 & 506 \\
\hline $60 \mathrm{t} / \mathrm{ha}$ & 492 & 453 & 464 & 446 & 512 \\
\hline \multicolumn{6}{|c|}{ aftereffect } \\
\hline Control & 319 & 317 & 342 & 303 & 399 \\
\hline $20 \mathrm{t} / \mathrm{ha}$ & 340 & 386 & 381 & 435 & 435 \\
\hline $30 \mathrm{t} / \mathrm{ha}$ & 481 & 457 & 396 & 503 & 568 \\
\hline $40 \mathrm{t} / \mathrm{ha}$ & 384 & 424 & 397 & 406 & 413 \\
\hline $50 \mathrm{t} / \mathrm{ha}$ & 400 & 382 & 392 & 473 & 546 \\
\hline $60 \mathrm{t} / \mathrm{ha}$ & 380 & 463 & 405 & 486 & 602 \\
\hline \multicolumn{6}{|c|}{$\begin{array}{l}\text { seedlings } \\
\text { act }\end{array}$} \\
\hline Control & 362 & 375 & 438 & 350 & 350 \\
\hline $20 \mathrm{t} / \mathrm{ha}$ & 362 & 375 & 450 & 388 & 550 \\
\hline $30 \mathrm{t} / \mathrm{ha}$ & 400 & 400 & 438 & 538 & 462 \\
\hline $40 \mathrm{t} / \mathrm{ha}$ & 400 & 325 & 475 & 562 & 462 \\
\hline $50 \mathrm{t} / \mathrm{ha}$ & 388 & 438 & 450 & 488 & 475 \\
\hline $60 \mathrm{t} / \mathrm{ha}$ & 350 & 438 & 350 & 425 & 612 \\
\hline \multicolumn{6}{|c|}{ aftereffect } \\
\hline Control & 388 & 325 & 488 & 588 & 338 \\
\hline $20 \mathrm{t} / \mathrm{ha}$ & 462 & 350 & 450 & 450 & 362 \\
\hline $30 \mathrm{t} / \mathrm{ha}$ & 500 & 538 & 462 & 350 & 450 \\
\hline $40 \mathrm{t} / \mathrm{ha}$ & 525 & 400 & 550 & 425 & 438 \\
\hline $50 \mathrm{t} / \mathrm{ha}$ & 462 & 462 & 538 & 350 & 512 \\
\hline $60 \mathrm{t} / \mathrm{ha}$ & 562 & 488 & 438 & 412 & 612 \\
\hline
\end{tabular}

\section{Conclusion}

Thus, per year the introduction of cattle manure in doses of 20-60 $\mathrm{t} /$ ha has a positive effect on the nutrient regime of the soil. The optimal storage time should be considered 8-12 months. With the introduction of manure of this storage duration in a dosage of 40-60 $\mathrm{t} / \mathrm{ha}$, the supply of plants from an average gradation turns into a very high one (more than 20.0 $\mathrm{mg} / \mathrm{kg}$ of soil). The content of available phosphorus and potassium also increases significantly.

In the first year of the aftereffect, manure doses continue to affect the nutrient regime of the soil. When manure is applied for 8-12 months, the storage duration at doses of 40-60 t / ha, the supply of plants from an average gradation in nitrate nitrogen goes into high (more than $16.0 \mathrm{mg} / \mathrm{kg}$ of soil). The content of available phosphorus and potassium also increases significantly. 


\section{References}

1. A. A. Shpedt, A. N. Petin, Y. N. Trubnikov, et al., International Journal of Green Pharmacy, 11(3), 610-614 (2017)

2. A. A. Shpedt, Y. V. Aksenova, Journal of Pharmaceutical Sciences and Research, 10(4), 870-873 (2018)

3. A. A. Shpedt, Yu. V. Aksenova, M. R. Shayakhmetov, et al., International Transaction Journal of Engineering, Management, \& Applied Sciences \& Technologies, 10(3), 309318 (2019)

4. I. A. Bobrenko, O. A. Matveychik, E. G. Bobrenko, V. I. Popova, Earth and Environmental Science, 624, 012219 (2021)

5. M. Shayakhmetov, A. Zinich, A. Gindemit, Advances in Intelligent Systems Research, 167, 156-159 (2019)

6. Y. Aksenova, N. Nevenchannaya, V. Boiko, et al., Advances in Social Science, Education and Humanities Research, 393, 50-54 (2019)

7. N. A. Voronkova, I. A. Bobrenko, N. M. Nevenchannaya, V. I. Popova, Efficiency of biologization of agriculture in Western Siberia (on the example of the Omsk region), in Proceedings of III International Scientific Conference: AGRITECH-III-2020: Agribusiness, Environmental Engineering and Biotechnologies, Krasnoyarsk Science and Technology City Hall of the Russian Union of Scientific and Engineering Associations, Krasnoyarsk, Russia (2020)

8. E. Zakharova, I. Perchatkina, D. Sultanov, Ecological Agriculture and Sustainable Development, 265-272 (2019)

9. N. Voronkova, L. Bashkatova, N. Balabanova, et al., Advances in Social Science, Education and Humanities Research, 393, 109-113 (2019)

10. Yu. A. Azarenko, Annals of Biology 35 (1), 67-72 (2019)

11. I. A. Bobrenko, V. V. Popova, N. V. Goman, A. A. Gaidar, Advances in Social Science, Education and Humanities Research, 393, 232-235 (2019)

12. I. A. Bobrenko, O. V. Shumakova, N. V. Goman, Y. I. Novikov, V. I. Popova, O. A. Blinov, Journal of Advanced Research in Law and Economics, VIII, 2(24), 426-436 (2017)

13. I. A. Bobrenko, V. P. Kormin, O. A. Matveychik, E. P. Boldysheva, Earth and Environmental Science, 624, 012062 (2021)

14. J. Fierro, J.E. Martínez, J.G. Rosas, D. Blanco, X. Gómez, Environmental Progress and Sustainable Energy, 33 (3), 866-872 (2014)

15. W. Zhang, Q. Lang, Z. Pan, Y. Jiang, J. Liebetrau, M. Nelles, H. Dong, R. Dong, Waste Manage, 64, 340-347 (2017)

16. V. I. Marchenko, D. A. Sidelnikov, D. I. Gritsai, E. V. Gerasimov, I. I. Shvetsov, Research Journal of Pharmaceutical, Biological and Chemical Sciences, 7(3), 19131918 (2016)

17. D. I. Eremin, Eurasian Soil Science, 49 (5), 538-545 (2016) 